\title{
CONCRETE BRIDGE WITH METALIC ENERGY DISSIPATION DEVICE
}

\author{
MSc. Ing Ricardo J. Uliarte \\ MSc. Ing Javier O. Morandi \\ Agustín Uliarte Victoria \\ Institute of Materials and Soils \\ Faculty of Engineering, National University of San Juan \\ San Juan, Argentina
}

\begin{abstract}
Most reinforced concrete road bridges built in Argentina have their foundations or substructure constructed at the job site. On the other hand, the superstructure typically used consists of precast I-beams with an in situ slab that gives a monolithic connection.
\end{abstract}

These beams are placed on top of elastomeric bearings, so relative movements between the substructure and the superstructure of the bridge may occur at the event of an earthquake. In order to limit these seismic displacements, buffers are constructed. They are reinforced concrete blocks fixed to the substructure. Their design is usually done following approximate hypothesis which, in highly seismic areas, may be very insecure.

The aim of this work is to show the improvement made in the dynamic response of the structure of the bridge built in the province of San Juan, Argentina, due to the addition of energydissipating devices.

In order to predict the seismic response of the structure, mathematical models have been developed. The energydissipating devices have been tested in the Lab to analyze their mechanical behavior. Results show that the damage over seismic buffers is significantly reduced, and therefore structural security is raised.

\section{Keywords- Energy. Dissipation. Devices. Bridges.}

\section{INTRODUCTION}

There have been built numerous road bridges in Argentina in high-risk seismic areas, following the layouts and structural diagram shown in Fig. 1, 2, 3 and 4. The superstructure can be appreciated and it consists of: guardrails, deck asphalt, panel slab, precast beams and cross ties. The substructure consists of the following elements: cross girder and concrete pile.

The cross girder (of the pile or the abutment) holds the support devices, constructed of rubber and steel. On top of these are placed the prestressed precast beams, which are then joined to each other and to the bridge deck by cast in situ concrete cross ties. On both sides of the precast beams are located the "seismic blocks", whose purpose is to avoid excessive displacement in the event of a seismic movement, disarming the original arrangement of the bridge elements and, for severe cases, reducing the possibility of the deck to fall. Figures 5 and 6.

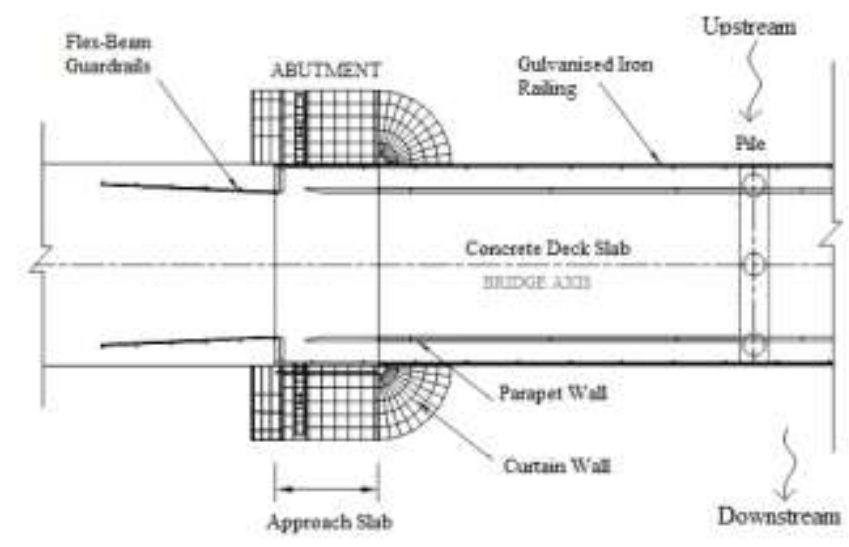

Figure 1. Plant of a section of Bridge that includes one abutment. 
Proc. of the Fifth International Conference on Advances in Civil, Structural and Environmental Engineering - ACSEE 2017. Copyright $($ Institute of Research Engineers and Doctors. All rights reserved.

ISBN: 978-1-63248-122-1 doi: 10.15224/ 978-1-63248-122-1-33

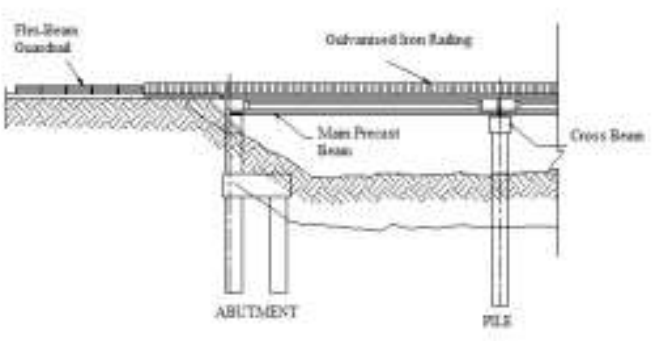

Figure 2. Longitudinal view

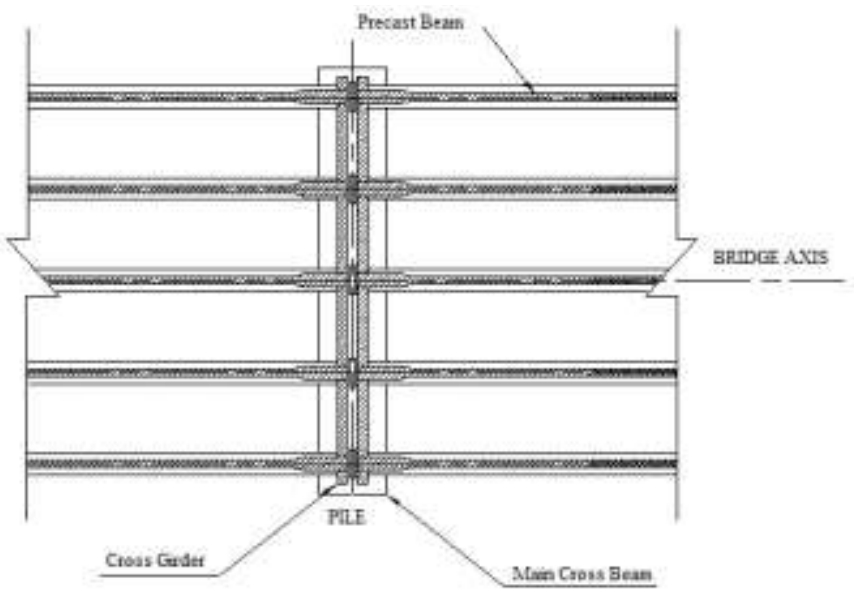

Figure 3. Plant showing the precast beams supported on the cross beam

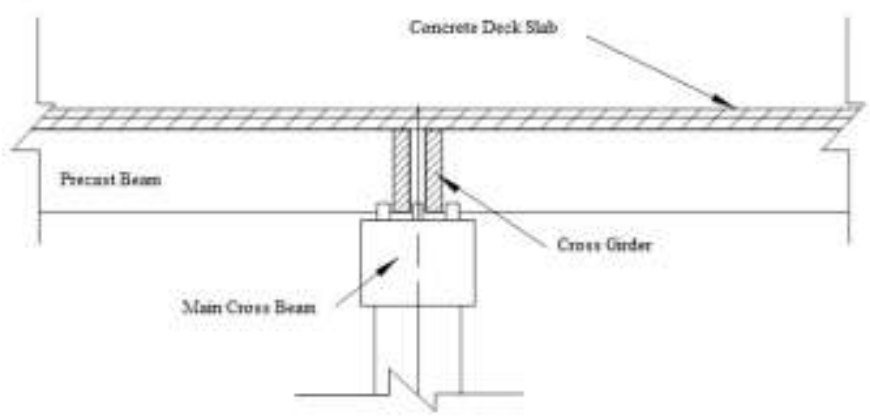

Figure 4. Longitudinal section showing cross tie

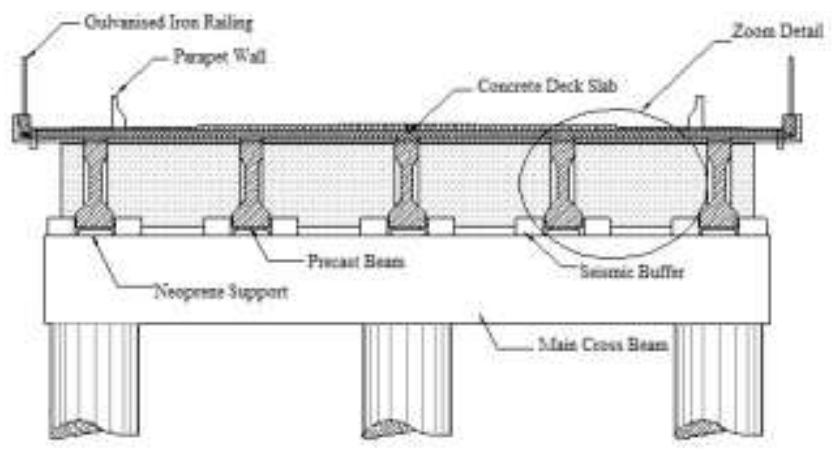

Figure 5. Cross Section of the Bridge

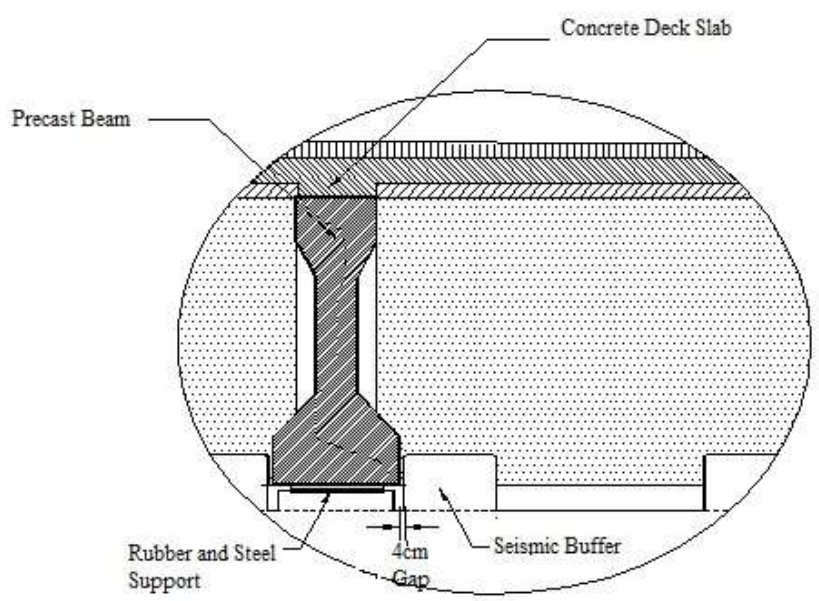

Figure 6. Detail of the support area of precast beam. The separation between the edge of the beam and the seismic buffer is normally about $4 \mathrm{~cm}$

\section{AIM OF WORK}

This work aims to demonstrate that the current design of seismic buffer for bridges is, in our opinion, incorrect and that it is possible to increase the safety of the structure incorporating energy dissipation devices that reduce the possibilities of impact and minimize the forces of collision between the structural elements of the bridge.

\section{CONVENTIONAL DESIGN OF SEISMIC BUFFERS}

Seismic buffers are generally designed static, considering a force that results from multiplying a seismic coefficient by the reaction of the precast beam. This coefficient is the result of the corresponding seismic response spectrum, reduced by a factor that considers the ductility of the structure.

\section{Example of Design of Seismic Buffers}

The built bridge has 12 sections of 25 meters length each. Five precast beams have been used per section. If the reaction (Rv) of each precast beam on the support device for a bridge 
Proc. of the Fifth International Conference on Advances in Civil, Structural and Environmental Engineering - ACSEE 2017. Copyright $($ Institute of Research Engineers and Doctors. All rights reserved.

ISBN: 978-1-63248-122-1 doi: 10.15224/ 978-1-63248-122-1-33

category A30 is calculated, following the designation of the National Roads Directorate, the obtained effort will be:

The design force "Fd", usually used for the design of each seismic buffer, is calculated as:

$\mathrm{Fd}=\mathrm{Cs} \times \mathrm{Rv}=0.35 \times 540.000 \mathrm{~N}=189.000 \mathrm{~N}$

with:

$\mathrm{Cs}=\mathrm{Sa} / \mathrm{R}=1.05 / 3=0.35$,

(Regulation INPRES CIRSOC 103)

Sa: seismic pseudo acceleration.

$\mathrm{R}=$ coefficient of reduction

If having a seismic buffer, with a cross section of $0.20 \mathrm{~m} \mathrm{x}$ $0.40 \mathrm{~m}$, at every beam, the shear stress will be:

$?(\mathrm{~N} / \mathrm{m} 2)=189.000 \mathrm{~kg} /(0.20 \times 0.40 \mathrm{~m})=2362.5 \mathrm{kN} / \mathrm{m} 2$.

IV. FORCES THAT CAN OCCUR DUE TO THE IMPACT OF THE MAIN BEAM HEEL WITH THE SEISMIC BUFFER AT A SEVERE SEISMIC MOVEMENT.

The bridge located Sorocayense, province of San JuanArgentina, was modeled using the sofware SAP 2000, version 7.4. The foundation soil consists of gravels with a medium to dense compaction degree (GP and GW). Spring elements were used to model the contact between the piles and the soil. At the board level the masses corresponding to the middle section of the bridge were assigned, considering only dead weights. The following seismic records were used in the analysis:

- Argentina: Caucete, November 23, 1977

- Chile: March 3, 1985, Llolleo N10E, Melipilla N20E and Viña N70W,

- USA: El Centro (Imperial Valley 1940), Corralitos NS (Loma Prieta 1989), Arleta EW and Sylmar NS (Northridge 1994)

- Mexico SCT (1985)

- Japan: Port Island (instrument 1) (Kobe 1995)

Using gap elements, the contact between the heel of the precast beam and the position of the seismic buffer was modeled, defining an opening of $4 \mathrm{~cm}$.

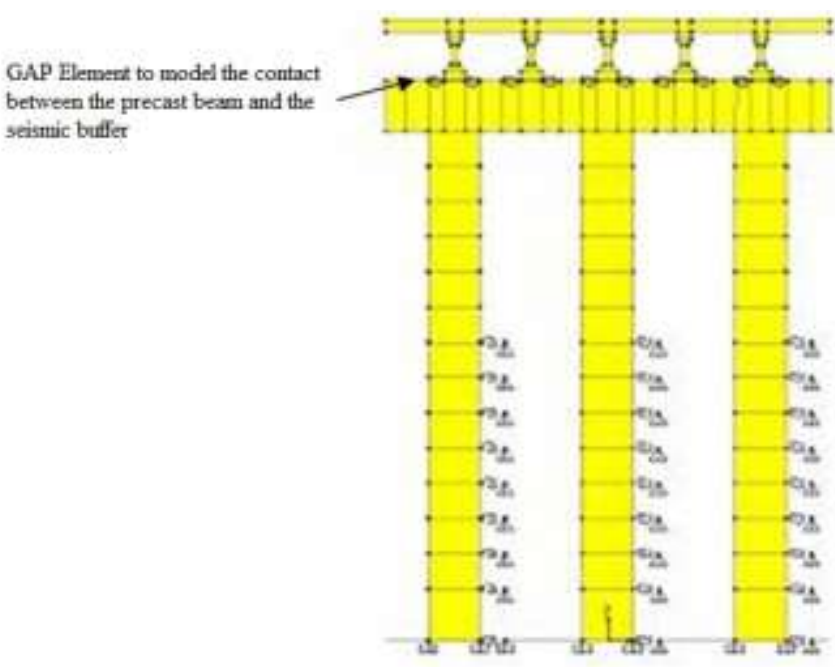

Figure 7. Model for Finite Element of the Bridge. Pile, Cross Beam, Precast beams and the Deck observed.

The following results presented in Table 1 are the outcome of the aforementioned analysis. It shows that the impact forces are far superior to those of a simplified static analysis, such as that described in section "Conventional Design of seismic buffers". This impact forces can surely cause significant damage to the structure. Figure 8 shows the beam at the time of contact with the buffer.

TABLE I. SUMMARY WORKSHEET OF EFFORTS ON SEISMIC BUFFERS

\begin{tabular}{|c|c|c|c|c|c|}
\hline REGISTER & $\begin{array}{l}\text { PLACE OF } \\
\text { REGISTER }\end{array}$ & \begin{tabular}{|c|} 
MAXIMUM \\
ACCELERATION \\
$(\% \mathrm{~g})$
\end{tabular} & $\begin{array}{c}\text { IMPACT } \\
\text { FORCE (Kn) }\end{array}$ & $\begin{array}{l}\text { STRESS AT } \\
\text { BUFFER } \\
(\mathrm{Kn} / \mathrm{m} 2)\end{array}$ & COMMENTS \\
\hline Caucete & San Juan - RA & $0,173 \mathrm{~g}$ & 1472 & 9200,0 & \multirow{9}{*}{$\begin{array}{l}\text { An important } \\
\text { structural damage is } \\
\text { estimated, due to the } \\
\text { exceeded shear } \\
\text { resistance. }\end{array}$} \\
\hline Melipilla & Chile & $0,686 \mathrm{~g}$ & 4416 & 27600,0 & \\
\hline Viña & Chile & $0,237 \mathrm{~g}$ & 2576 & 16100,0 & \\
\hline El Centro & E.E. U.U. & $0,358 \mathrm{~g}$ & 3680 & 23000,0 & \\
\hline Sylmar & E.E. U.U. & $0,843 \mathrm{~g}$ & 5299,2 & 33120,0 & \\
\hline Arleta & E.E. U.U. & $0,344 \mathrm{~g}$ & 4416 & 27600,0 & \\
\hline Corralito & E.E. U.U. & 0,629 & 2944 & 18400,0 & \\
\hline México & México & $0,171 \mathrm{~g}$ & 5152 & 32200,0 & \\
\hline Kobe & Japón & $0,310 \mathrm{~g}$ & 4416 & 27600,0 & \\
\hline
\end{tabular}

g: acceleration of gravity

Buffer: Seismic resistant buffer 
Proc. of the Fifth International Conference on Advances in Civil, Structural and Environmental Engineering - ACSEE 2017. Copyright $($ Institute of Research Engineers and Doctors. All rights reserved.

ISBN: 978-1-63248-122-1 doi: 10.15224/ 978-1-63248-122-1-33

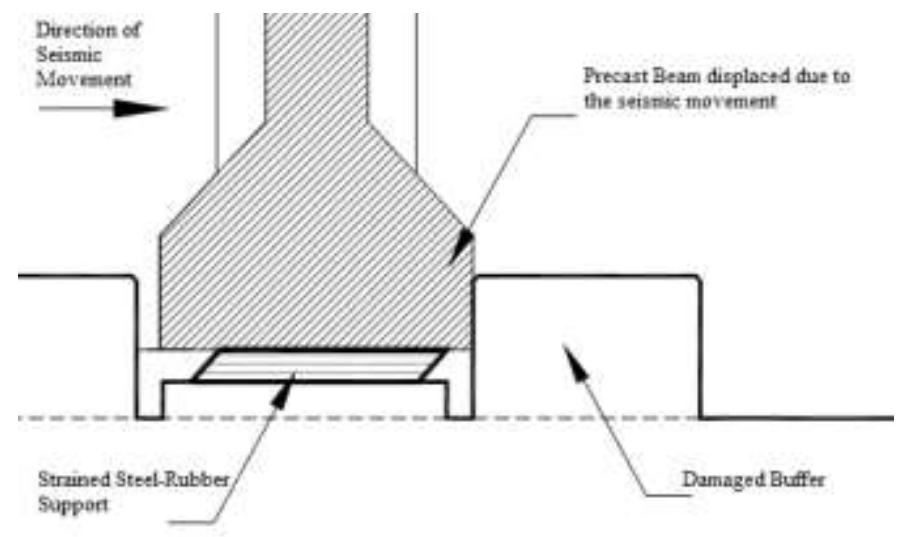

Figure 8. Displacement of the precast beam during the earthquake that can cause damage to the structure

\section{ENERGY-DiSSIPATION DEVICES. BRIEF REVIEW.}

All vibrating structures dissipate energy due to internal frictions, plastic deformations or a combinations of both. It is a fact that the greater is the dissipation of energy, the smaller is the amplitude of the vibrations. Some structures have a very low damping, about $1 \%$ of the critical, and consequently experience great amplitudes of vibration for severe and moderate earthquakes, that is why the techniques that improve dissipation energy are very effective in reducing the amplitudes of vibration. Many systems have been proposed and used to increase the damping of structures at the present, constructed of different materials and devices. These systems can be used in new structures such as in those that need to be repaired.

In last years, important advances have been made for the developing of the concept of passive dissipation and many structures in the world have these devices. In general they are characterized by increasing the dissipation capacity of the structures where they are installed on.

Energy dampers work either by converting kinetic energy to heat or by transferring energy between different modes of vibration. The first method includes devices that operate on the principle of friction due to displacement, metal fluency, phase transformation in metals, strain of viscoelastic solid elements, forcing viscous liquids to flow through holes. The second method is based on adding supplementary oscillators that work as dynamic vibration absorbers.

Below are some of the best known, along with its main characteristics.

- Metallic Energy-Dampers: One of the effective mechanisms for dissipation of energy is through the inelastic deformation of metals. The idea of using metal dampers in structures to absorb the energy that earthquakes introduce into them, began with the conceptual and experimental work of Robert Kelly and Skinner.
- Frictional Dampers: Friction is an excellent mechanism for energy dissipation that has been used in the automotive industry in automobile brakes, transforming the kinetic energy into heat.

A wide variety of devices have been proposed and developed in Structural Engineering, that differ from each other in the mechanical complexity and the materials in which they slide on. It is important to minimize the stick-slip phenomenon in order to avoid high frequency excitation. It should be ensured that the selected slip material does not significantly alter the coefficient of friction after time. The design idea for these dumpers is that they do not slide for moderate earthquakes or wind induced loads.

Usually these devices have an adequate performance and are not affected by the amplitude of the loads, the frequency, or the number of cycles. The design of structures with these devices requires a nonlinear analysis in the time domain.

- Viscoelastic Dampers: Metallic and frictional dampers are primarily used to reduce the effects of earthquakes on structures, whereas dampers made of viscoelastic materials can be used to reduce vibrations caused by wind and / or earthquakes.

The behavior of viscoelastic materials under dynamic loads depends on the frequency of the excitation, the strain and the ambient temperature. Recent experiments and analytical studies have demonstrated the effectiveness of viscoelastic dampers used in steel and reinforced concrete structures for a wide range of earthquakes.

- Viscous Fluids Dampers: Fluids can be used to dissipate energy and therefore have been applied in numerous designs. One type of these energy dissipation devices consists of a cylindrical piston submerged in a viscoelastic fluid. Viscous fluids dampers have been employed in military and aerospace constructions. Their characteristic is that they have viscous linear response for a wide range of frequencies.

- $\quad$ Tuned Mass Dampers (TMD): The concept of Tuned Mass Dampers (TMD) dates from the 40s. It consists of a secondary mass with an element that links it to the primary structure and gives it certain rigidity. The hysteresis cycles that occur increase the damping in the primary structure.

\section{ENERGy Dissipation DeVice Proposed FOR THE BRIDGE}

In the Project of the bridge in Sorocayense it was decided to adapt a Metallic Damper. The reason for this selection is its economy, since no special materials or techniques are required 
Proc. of the Fifth International Conference on Advances in Civil, Structural and Environmental Engineering - ACSEE 2017. Copyright ( $\odot$ Institute of Research Engineers and Doctors. All rights reserved.

ISBN: 978-1-63248-122-1 doi: 10.15224/ 978-1-63248-122-1-33

for its manufacture, and can be built at any workshop equipped with a lathe. The material used in this case is Steel SAE 1010. Fig. 9, 10 and 11 show the chosen location of the damper in order to capture the relative displacement between the superstructure and substructure. Pictures 1, 2 and 3 show the device used on the Sorocayense bridge.

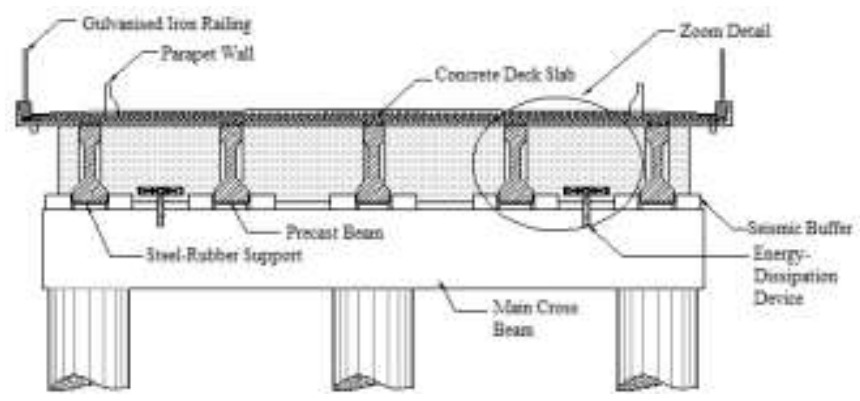

Figure 9. Cross Section of the bridge- Position of the Metallic Damper

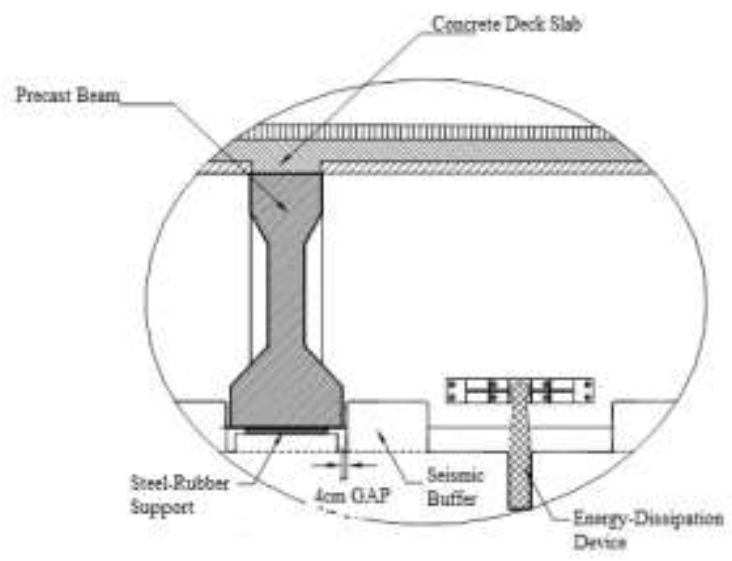

Figure 10. Detail of the support area of precast beam. See $4 \mathrm{~cm}$ Gap

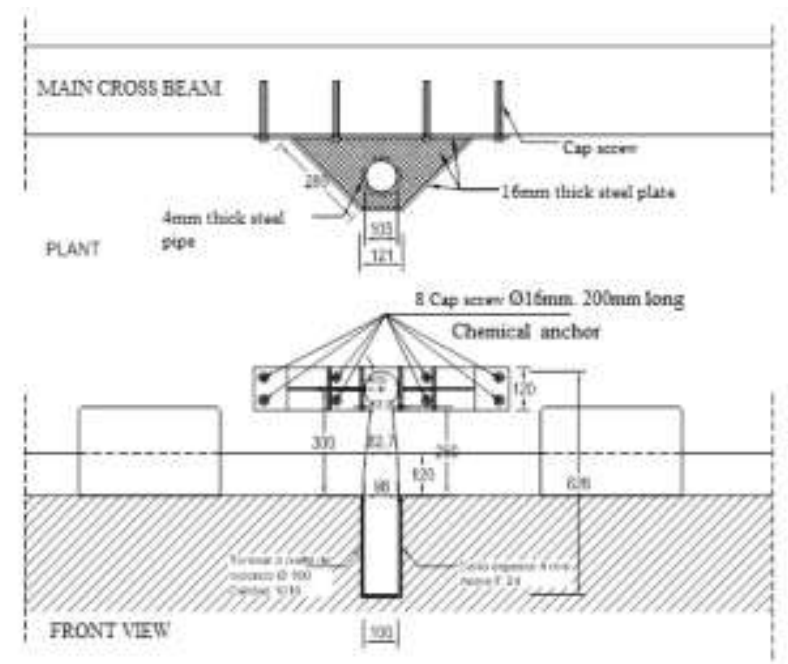

Figure 11. Outline of the proposed dumper

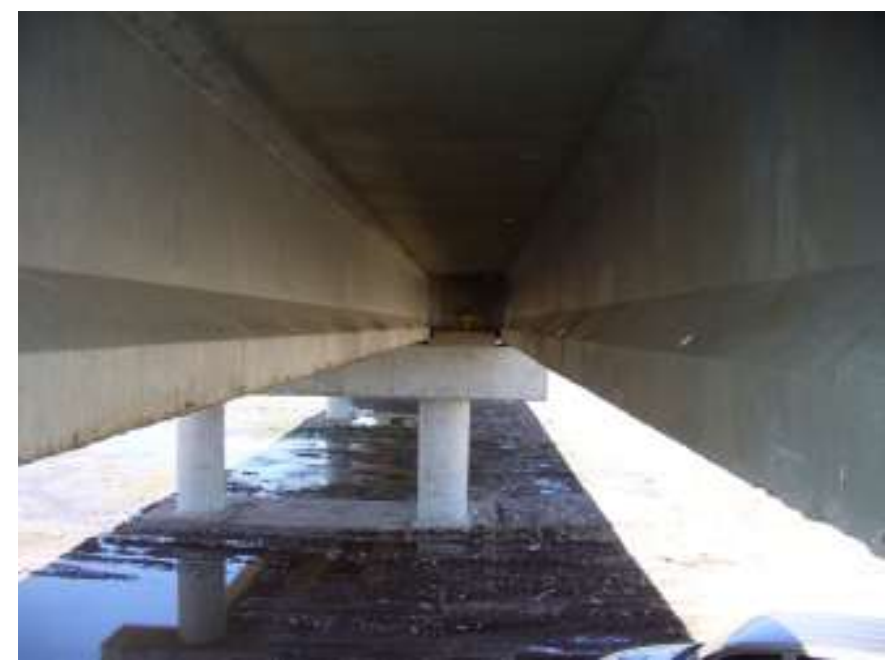

Figure 12. View of the dumper. Bridge in Sorocayense, San Juan-Argentina

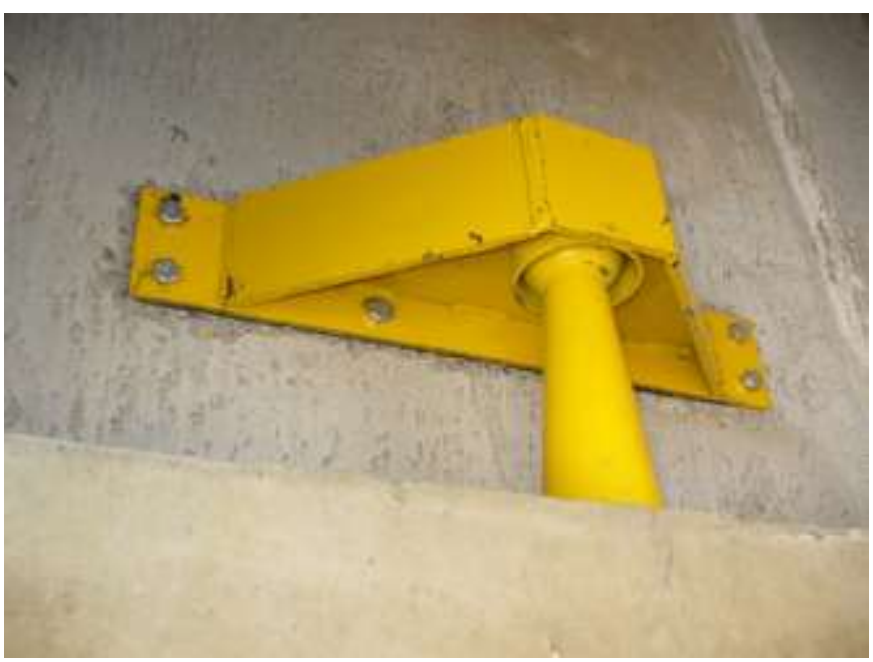

Figure 13. Damper used in the bridge in Sorocayense

\section{TESTS TO OBTAIN PROPERTIES}

A geometric design of the dissipation device was modeled and then it was tested to obtain its constitutive law. The results of these tests were used in the mathematical modeling that was performed to obtain the bridge behavior with the incorporation of these devices. The pictures No. 3 and No. 4 show a prototype dumper after being tested. 
Proc. of the Fifth International Conference on Advances in Civil, Structural and Environmental Engineering - ACSEE 2017. Copyright $@$ Institute of Research Engineers and Doctors. All rights reserved.

ISBN: 978-1-63248-122-1 doi: 10.15224/ 978-1-63248-122-1-33

\section{RESULT OF INCORPORATING THE HEATSINKS TO THE BRIDGE}

TABLE II. SUMMARY OF THE RELATIVE DISPLACEMENTS BETWEEN THE SUPERSTRUCTURE AND INFRASTRUCTURE BY INCORPORATING THE HEATSINKS

\begin{tabular}{|c|c|c|c|}
\hline REGISTER & $\begin{array}{l}\text { PLACE OF } \\
\text { REGISTER }\end{array}$ & $\begin{array}{l}\text { MAXIMUM RELATIVE } \\
\text { DISPLACEMENTE }(\mathrm{cm})\end{array}$ & OBSERVATIONS \\
\hline Caucete & San Juan - RA & 2,4 & \multirow{4}{*}{$\begin{array}{l}\text { No impact at the buffer. } \\
\text { The displacement is smaller } \\
\text { than the } 4 \mathrm{~cm} \text { gap. }\end{array}$} \\
\hline Melipilla & Chile & 3,9 & \\
\hline Viña & \begin{tabular}{|l|} 
Chile \\
\end{tabular} & 3,0 & \\
\hline El Centro & E.E. U.U. & 3,6 & \\
\hline Sylmar & E.E. U.U. & 4,0 & $\begin{array}{l}\text { Impact at the buffer } \\
\text { registered }\end{array}$ \\
\hline Arleta & E.E. U.U. & 3,7 & \multirow{4}{*}{$\begin{array}{l}\text { No impact at the buffer. } \\
\text { The displacement is smaller } \\
\text { than the } 4 \mathrm{~cm} \text { gap. }\end{array}$} \\
\hline Corralito & E.E. U.U. & 3,0 & \\
\hline México & México & 3,9 & \\
\hline Kobe & Japón & 3,6 & \\
\hline
\end{tabular}

\section{FINAL COMMENTS}

Table 1 and Table 2 summarize the results of this work. In the case of incorporating energy dumpers, impact at the buffer is observed only for the Sylmar register, but with a smaller force. If the bridge were truly exposed to an earthquake like Sylmar's, the alternative is to place a more robust damper.

Construction work has been completed at the Sorocayense bridge. The work was carried out within 18 months.

The cost of incorporating energy dissipation devices is less than $0.8 \%$ of the value of the complete structure. It is considered that this amount is insignificant in the face of the good behavior shown in the computer analyzes performed and the laboratory tests of the same.

The design allows replacement of the metallic dampers when they are seriously damaged as they act as fuse elements.

\section{SERVICE LifE ESTIMATION}

TABLE III. STRAIN E1 IS APPLIED UNTIL 50\% OF SERVICE LIFE IS OVERCOME AND THEN E2 IS APPLIED COUNTING THE NUMBER OF CYCLES. RESULTS CAN BE APPRECIATED IN THE TABLE.

\begin{tabular}{|c|c|c|c|c|c|c|c|c|}
\hline \multicolumn{9}{|c|}{ SERIE DE ENSAYOS № 1} \\
\hline \multicolumn{9}{|c|}{ Número de Cilcos para el $50 \%$ de la Vida Útil } \\
\hline \multicolumn{9}{|c|}{ Deformación específica $\varepsilon 2(\%)$} \\
\hline & & $1 \%$ & $2 \%$ & $3 \%$ & $4 \%$ & $5 \%$ & $6 \%$ & $7 \%$ \\
\hline \multirow{7}{*}{ 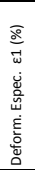 } & $1 \%$ & 337 & 101 & 49 & 46 & 25 & 20 & 19 \\
\hline & $2 \%$ & 304 & 112 & 51 & 41 & 22 & 18 & 18 \\
\hline & $3 \%$ & 398 & 120 & 69 & 30 & 34 & 28 & 15 \\
\hline & $4 \%$ & 218 & 124 & 54 & 41 & 31 & 18 & 13 \\
\hline & $5 \%$ & 225 & 104 & 58 & 30 & 28 & 16 & 15 \\
\hline & $6 \%$ & 345 & 92 & 58 & 34 & 29 & 13 & 14 \\
\hline & $7 \%$ & 308 & 104 & 59 & 30 & 26 & 19 & 16 \\
\hline
\end{tabular}

TABLE IV. STRAIN E1 IS APPLIED UNTIL 50\% OF SERVICE LIFE IS OVERCOME
AND THEN E2 IS APPLIED COUNTING THE NUMBER OF CYCLES. RESULTS CAN BE APPRECIATED IN THE TABLE.

\begin{tabular}{|c|c|c|c|c|c|c|c|c|}
\hline \multicolumn{9}{|c|}{ SERIE DE ENSAYOS № 2} \\
\hline \multicolumn{9}{|c|}{ Número de Cilcos para el $50 \%$ de la Vida Útil } \\
\hline \multicolumn{9}{|c|}{ Deformación específica } \\
\hline & & $1 \%$ & $2 \%$ & $3 \%$ & $4 \%$ & $5 \%$ & $6 \%$ & $7 \%$ \\
\hline \multirow{7}{*}{ 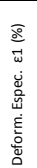 } & $1 \%$ & 334 & 106 & 57 & 48 & 20 & 21 & 19 \\
\hline & $2 \%$ & 292 & 120 & 53 & 43 & 23 & 18 & 17 \\
\hline & $3 \%$ & 411 & 113 & 67 & 27 & 33 & 25 & 17 \\
\hline & $4 \%$ & 247 & 107 & 60 & 45 & 27 & 19 & 12 \\
\hline & $5 \%$ & 221 & 110 & 58 & 31 & 31 & 16 & 13 \\
\hline & $6 \%$ & 318 & 92 & 62 & 35 & 30 & 13 & 16 \\
\hline & $7 \%$ & 278 & $91 \mid$ & 56 & 31 & 24 & 19 & 18 \\
\hline
\end{tabular}

TABLE V. STRAIN E1 IS APPLIED UNTIL 50\% OF SERVICE LIFE IS OVERCOME AND THEN E2 IS APPLIED COUNTING THE NUMBER OF CYCLES. RESULTS CAN BE APPRECIATED IN THE TABLE.

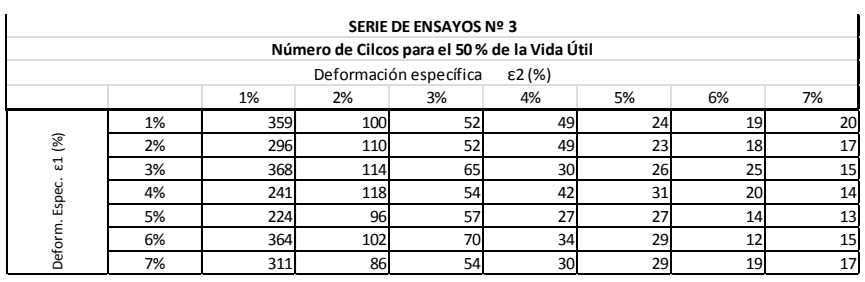

TABLE VI. STRAIN E1 IS APPLIED UNTIL 50\% OF SERVICE LIFE IS OVERCOME AND THEN E2 IS APPLIED COUNTING THE NUMBER OF CYCLES. RESULTS CAN BE APPRECIATED IN THE TABLE.

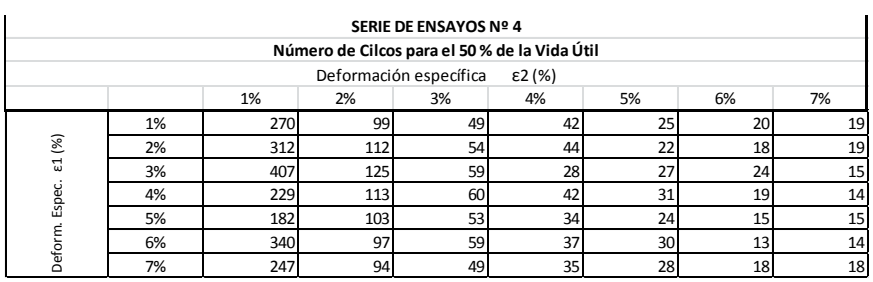

TABLE VII. STRAIN E1 IS APPLIED UNTIL 50\% OF SERVICE LIFE IS OVERCOME AND THEN E2 IS APPLIED COUNTING THE NUMBER OF CYCLES. RESULTS CAN BE APPRECIATED IN THE TABLE.

\begin{tabular}{|c|c|c|c|c|c|c|c|c|}
\hline \multicolumn{9}{|c|}{ SERIE DE ENSAYOS № 5} \\
\hline \multicolumn{9}{|c|}{ Número de Cilcos para el $50 \%$ de la Vida Útil } \\
\hline \multicolumn{9}{|c|}{ Deformación específica } \\
\hline & & $1 \%$ & $2 \%$ & $3 \%$ & $4 \%$ & $5 \%$ & $6 \%$ & $7 \%$ \\
\hline \multirow{7}{*}{ 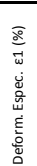 } & $1 \%$ & 386 & 112 & 61 & 48 & 22 & 21 & 18 \\
\hline & $2 \%$ & 313 & 122 & 56 & 45 & 22 & 20 & 18 \\
\hline & $3 \%$ & 408 & 113 & 62 & 31 & 32 & 25 & 15 \\
\hline & $4 \%$ & 242 & 128 & 56 & 48 & 27 & 16 & 14 \\
\hline & $5 \%$ & 249 & 105 & 61 & 28 & 26 & 15 & 15 \\
\hline & $6 \%$ & 382 & 102 & 59 & 37 & 29 & 13 & 16 \\
\hline & $7 \%$ & 269 & 101 & 56 & 32 & 26 & 17 & 17 \\
\hline
\end{tabular}

TABLE VIII. STRAIN E1 IS APPLIED UNTIL 50\% OF SERVICE LIFE IS OVERCOME AND THEN E2 IS APPLIED COUNTING THE NUMBER OF CYCLES. RESULTS CAN BE 
Proc. of the Fifth International Conference on Advances in Civil, Structural and Environmental Engineering - ACSEE 2017. Copyright $($ Institute of Research Engineers and Doctors. All rights reserved.

ISBN: 978-1-63248-122-1 doi: 10.15224/ 978-1-63248-122-1-33

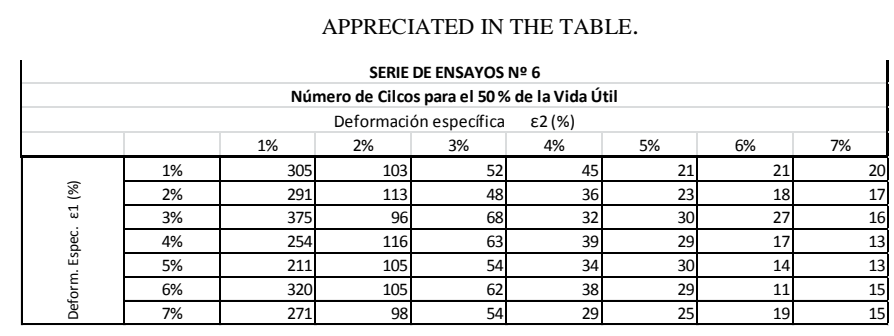

TABLE IX. STRAIN E1 IS APPLIED UNTIL 50\% OF SERVICE LIFE IS OVERCOME AND THEN E2 IS APPLIED COUNTING THE NUMBER OF CYCLES. RESULTS CAN BE APPRECIATED IN THE TABLE.

\begin{tabular}{|c|c|c|c|c|c|c|c|c|}
\hline \multicolumn{9}{|c|}{ SERIE DE ENSAYOS № 7} \\
\hline \multirow{2}{*}{\multicolumn{9}{|c|}{ Deformación específica $\quad \varepsilon 2(\%)$}} \\
\hline & & $1 \%$ & $2 \%$ & & & $5 \%$ & & \\
\hline \multirow{7}{*}{ 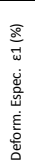 } & $1 \%$ & 357 & 104 & \begin{tabular}{l|l|}
53 \\
\end{tabular} & 41 & 23 & 21 & 19 \\
\hline & $2 \%$ & 321 & 118 & 49 & 46 & 24 & 19 & 17 \\
\hline & $3 \%$ & 360 & 113 & 58 & 32 & 29 & 27 & 18 \\
\hline & $4 \%$ & 240 & 113 & 58 & 42 & 26 & 20 & 11 \\
\hline & $5 \%$ & 194 & 104 & 51 & 35 & 24 & 16 & 15 \\
\hline & $6 \%$ & 354 & 93 & 66 & 35 & 27 & 11 & 16 \\
\hline & $7 \%$ & 288 & 99 & 53 & 31 & 28 & 18 & 17 \\
\hline
\end{tabular}

TABLE X. STRAIN E1 IS APPLIED UNTIL 50\% OF SERVICE LIFE IS OVERCOME AND THEN E2 IS APPLIED COUNTING THE NUMBER OF CYCLES. RESULTS CAN BE APPRECIATED IN THE TABLE.

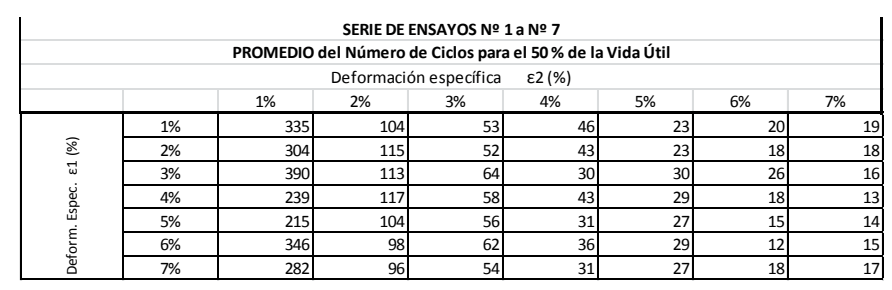

TABLE XI. STRAIN E1 IS APPLIED UNTIL 50\% OF SERVICE LIFE IS OVERCOME AND THEN E2 IS APPLIED COUNTING THE NUMBER OF CYCLES. RESULTS CAN BE APPRECIATED IN THE TABLE.

\begin{tabular}{|c|c|c|c|c|c|c|c|c|}
\hline \multicolumn{9}{|c|}{$\begin{array}{c}\text { SERIE DE ENSAYOS № } 1 \text { a № } 7 \\
\text { VIDA ÚTIL }\end{array}$} \\
\hline \multicolumn{9}{|c|}{ Deformación específica $\quad \varepsilon 2(\%)$} \\
\hline & & $1 \%$ & $2 \%$ & $3 \%$ & $4 \%$ & $5 \%$ & $6 \%$ & $7 \%$ \\
\hline \multirow{7}{*}{ 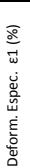 } & $1 \%$ & 0.995 & 0.967 & $\begin{array}{ll}0.963 \\
\end{array}$ & 1.139 & 0.952 & 1.068 & 1.225 \\
\hline & $2 \%$ & 0.920 & 1.030 & 0.962 & 1.105 & 0.970 & 1.032 & 1.161 \\
\hline & $3 \%$ & 1.069 & 0.998 & 1.022 & 0.026 & 1.079 & 1.262 & 1.076 \\
\hline & $4 \%$ & 0.834 & 0.987 & 1.001 & 1.097 & 1.084 & 1.024 & 1.002 \\
\hline & $5 \%$ & 0.808 & 0.957 & 0.964 & 0.924 & 1.072 & 0.927 & 1.030 \\
\hline & $6 \%$ & 0.994 & 0.924 & 1.055 & 0.976 & 1.079 & 0.841 & 1.099 \\
\hline & $7 \%$ & 0.907 & 0.926 & 0.986 & 0.935 & 1.039 & 1.024 & 1.113 \\
\hline
\end{tabular}

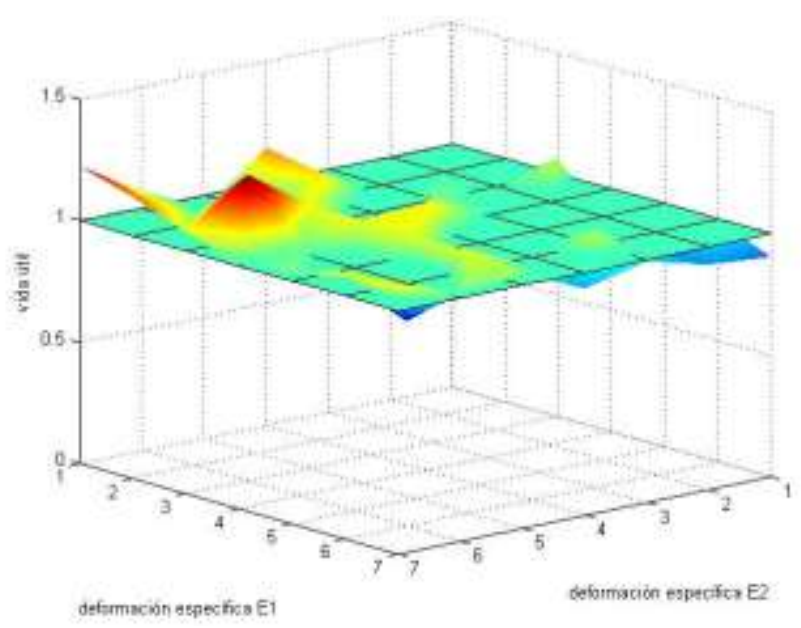

Figure 14. Serive Life

\section{PROPOSSED EXPRESION TO CALCULATE FATIGUE DAMAGE}

After processing test resutls with an optimization function of Matlab, which minimizes the quadratic error between the proposed expression and the test results. The function that best represents the estimation of the service life is the following:

$$
\mathrm{N}=574 \varepsilon^{-\left(1,58+\frac{\varepsilon}{2,5 \varepsilon_{r}}\right)}
$$

$\varepsilon_{r}:$ Rupture strain obtained from an axial traction test.

$\varepsilon:$ Specific strain for a cycle

$\mathrm{N}$ : Number of cycles until rupture

The expression contemplates the fact of having cycles of different amplitude for the same external excitation. This function with the Miner's Rule together, allows the estimation of damage that a cycle produces to the specific strain " $\varepsilon$ ".

This expression is obtained from a combination of different specific strain tests. For any excitation, such as an earthquake, complete cycles must be counted using the Miner rule (Palgrem-Miner et al, 1945) for which there is a routine developed in Matlab to perform this calculation.

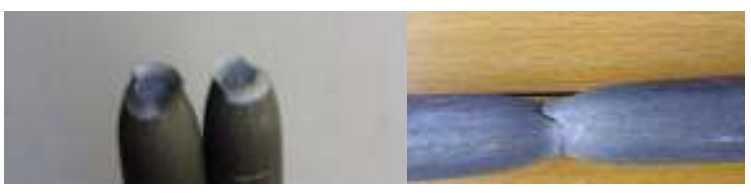

Figure 15. Traction test of a steel bar 
Proc. of the Fifth International Conference on Advances in Civil, Structural and Environmental Engineering - ACSEE 2017. Copyright $(\odot$ Institute of Research Engineers and Doctors. All rights reserved.

ISBN: 978-1-63248-122-1 doi: 10.15224/ 978-1-63248-122-1-33
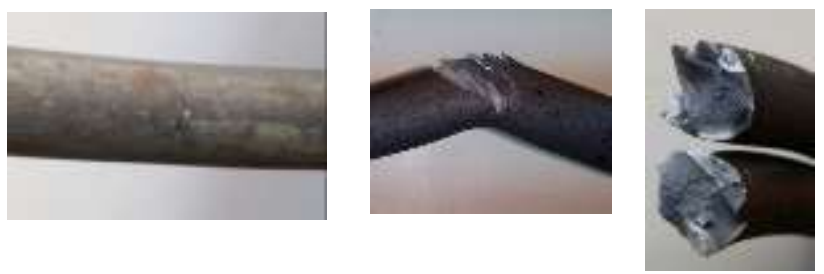

Figure 16. Fatigue damage and rupture due to fatigue

\section{CONCLUSIONS}

- The conventional static design is insufficient to estimate the impact forces between the beam and the seismic buffer.

- The incorporation of Energy Sinks substantially increases the safety of the analyzed bridge at a very reasonable cost.

- The displacement and impact force are controlled in one of the most critical elements as is the lower part of the support of the precast beam.

\section{BIBLIOGRAPHIC REFERENCES}

Books:

[1] Bozorgnia, Yousef Bertero, Vitelma V. (2004). Earthquake Engineering: from engineering seismology to performance based engineering. CRC Press.

[2] Chen, WaiFah Duan Lian. (2003). Bridge Engineering: Seismic design. CRC Press.

[3] Chen, WaiFah Duan Lian. (2003). Bridge Engineering: Substructure design. CRC Press.

[4] Priestly, MJN Seible, F. Calvi, GM (1996). Seismic Design and Retrofit of Wile and bridges Interscience Publication.

[5] Uliarte, Ricardo. (1998) Passive Energy Dissipation Systems for Reducing Vibrations in Structures: Analysis and Design. Pontifical Catholic University of Chile Thesis for degree of Master of Engineering Sciences. Chile.

Conferences, conferences and seminars:

[6] Uliarte, Ricardo et al (2008). Passive Energy Dissipation Systems in Road Bridges. 20th Argentine Conference on Structural Engineering. Asociation of Structural Engineers. City of Buenos Aires, Argentina. ASAEE-South American Association of Structural Engineering Page: www.asaee.org.br 